\title{
Differential Regulation of Corticotropin-Releasing Factor mRNA in Rat Brain Regions by Glucocorticoids and Stress
}

\author{
Toshihiro Imaki, ${ }^{1}$ Jean-Louis Nahan, ${ }^{1}$ Catherine Rivier,, P. E. Sawchenko,, ${ }^{2}$ and Wylie Vale ${ }^{1}$ \\ 'Clayton Foundation Laboratories for Peptide Biology and 'Laboratory of Neuronal Structure and Function, The Salk \\ Institute, La Jolla, California 92037
}

The regulation of corticotropin-releasing factor (CRF) mRNA expression in the rat brain by glucocorticoids and stress was examined by Northern blot analysis and in situ hybridization histochemistry. Rats either were exposed to a single electrical footshock session and killed 2, 4, 12, or $24 \mathrm{hr}$ later (acute stress), or were subjected to the same regimen twice daily for 3 or $7 \mathrm{~d}$ and killed on the day following the last session (chronic stress). Rats placed in the experimental chamber but not administered shock comprised a "shamhandling" group.

Chronic (7 d) intermittent footshock stress resulted in an $84 \pm 26 \%(P<0.05)$ increase in CRF mRNA levels in the whole hypothalamus as detected by Northern blot analysis and a $97 \pm 29 \%(P<0.05)$ increase in the paraventricular nucleus (PVN) as detected using in situ hybridization. No significant change in CRF mRNA levels was observed in the hypothalamus at any time up to $24 \mathrm{hr}$ after a single exposure to footshock stress.

A different pattern of results was obtained in other CRFexpressing cell groups. In Barrington's nucleus (a pontine micturition center), both acute and chronic stress produced significant increases in CRF mRNA, while in the olfactory bulb, both paradigms resulted in decreased levels. By Northern blot analysis, CRF mRNA in the olfactory bulb declined steadily, beginning at $\mathbf{4} \mathrm{hr}$ after acute stress, and reached significance at $24 \mathrm{hr}(69.2 \pm 1.9 \%$ of control, $P<0.05)$. Levels from chronically (7 d) stressed animals declined to $54.1 \pm 5.1 \%$ of control value $(P<0.05)$. Analysis of hybridization histochemical material revealed that both the number of positively hybridized cells and the number of silver grains per cell in the mitral and external plexiform layers of the bulb decreased following acute and chronic stress. However, CRF mRNA levels in the olfactory bulb were decreased to a comparable extent in the sham-handling group, suggesting that

\footnotetext{
Received Apr. 23, 1990; revised Aug. 3, 1990; accepted Aug. 10, 1990.

We thank Dr. K. Mayo (Northwestern University) for a gift of rat CRF cDNA plasmid. We are grateful to D. Simmons, J. Arriza, and L. Swanson (The Salk Institute) for sharing their unpublished protocol with us, to $\mathrm{H}$. Meunier, F. Presse, $J$. Imaki, and Y. Murakami for helpful discussions on the experiment, and to $\mathbf{M}$ Mortrud for technical assistance. This work was supported by NIH Grants DK26714 and NS-21181 and grants from the Adler Foundation and Robert J. Kleberg and Helen $C$. Kleberg Foundation and was conducted in part by the Clayton Foundation for Research, California Division. P.E.S., C.R., and W.V. are Clayton Foundation Investigators. T.I. is the recipient of a fellowship from the Foundation for Growth Science in Japan.

Correspondence should be addressed to Dr. W. Vale, Clayton Foundation Laboratories for Peptide Biology, The Salk Institute, P.O. Box 85800, San Diego, CA 92138.

Copyright (C) 1991 Society for Neuroscience $0270-6474 / 91 / 110585-15 \$ 03.00 / 0$
}

exposure to a novel environment can effect a decrease in CRF mRNA levels in the olfactory bulb.

To provide comparisons with the effects of manipulation of glucocorticoid status, comparable analyses were carried out in separate groups of animals following adrenalectomy (ADX) with and without corticosteroid replacement. After ADX, CRF mRNA levels in the whole hypothalamus increased 60 $\pm 5 \%(P<0.05)$ and were normalized following dexamethasone replacement. In contrast to the hypothalamus, no effects of steroid manipulation on CRF mRNA levels in the olfactory bulb, midbrain, cerebral cortex, or brain stem were detected. In situ hybridization revealed that ADX induced a significant increase $(285 \pm 49 \%$ of control, $P<0.05)$ in CRF mRNA levels in the PVN, while having no effect on levels in Barrington's nucleus.

These results provide evidence for pronounced regional differences in the regulation of CRF mRNA by glucocorticoids and stress. In line with recent reports, CRF mRNA in the PVN is negatively regulated by glucocorticoids and positively regulated by prolonged exposure to footshock stress, though in this paradigm, at least, a single episode of acute stress was not sufficient to up-regulate CRF mRNA levels in the PVN. The expression of CRF mRNA in Barrington's nucleus is also positively regulated by stress, suggesting a possible role for CRF in stress-induced micturition. In the olfactory bulb, stress and/or factors related to novel environments down-regulate CRF mRNA. Glucocorticoids appear not to be a major factor influencing CRF mRNA expression in Barrington's nucleus or the olfactory bulb.

Corticotropin-releasing factor (CRF) is a 41 -residue hypophysiotropic peptidc first isolatcd and sequenced from the ovine hypothalamus (Vale et al., 1981) and subsequently characterized in several species, including the rat (I. Rivier et al., 1982) and the human (Shibahara et al., 1983). There is now general agreement that a circumscribed group of parvocellular neurosecretory neurons localized in the paraventricular nucleus of the hypothalamus (PVN) comprises the principal source for the delivery of CRF to the portal capillary zone of the median eminence, though CRF is quite broadly expressed throughout the CNS (for reviews, see Antoni, 1986; Sawchenko and Swanson, 1990). Stress-induced activation of the pituitary-adrenal axis and the consequent increase in plasma ACTH and glucocorticoid levels are dependent upon CRF (C. Rivier et al., 1982; Rivier and Plotsky, 1986). Apart from its effect on the pituitary, CRF has been implicated as acting within the CNS to influence a number of behavioral, neuroendocrine, and autonomic responses to stress 
(Vale et al., 1983; Brown and Fisher, 1985; Koob and Bloom, 1985), raising the possibility that central CRF systems may act or interact in a unified manner to integrate multimodal components of the organismic response to stress.

Many reports have described changes in CRF bioactivity and CRF-like immunoreactivity in the hypothalamus after acute or chronic stress (e.g., Sato et al., 1975; Hiroshige et al., 1977; Moldow and Fischman, 1982; Suemaru et al., 1985; Chappell et al., 1986; Moldow et al., 1986; Haas and George, 1988). However, results of experiments measuring CRF content in tissues after stress have been conflicting, possibly because there are many CRF neurons that do not participate in the regulation of the pituitary-adrenal axis (Beyer et al., 1988) and because content measures may be separately affected by rates of synthesis, transport, secretion, and degradation. The isolation of a cDNA that encodes the rat prepro-CRF (Jingami et al., 1985a) and the development of in situ hybridization histochemical tcchniques have provided tools with which to monitor CRF mRNA levels and, thereby, to infer effects of experimental circumstances on the regulation of CRF expression in the tuberoinfundibular system and in other brain regions.

It is now well established that CRF mRNA and peptide expression in the hypothalamus (PVN) are negatively regulated by glucocorticoids (Jingami et al., 1985b; Young et al., 1986; Kovacs and Mezey, 1987; Sawchenko, 1987; Beyer et al., 1988; Swanson and Simmons, 1989). More recently, it has been shown that several stressors, including hypertonic saline injection (Lightman and Young, 1988), insulin-induced hypoglycemia (Suda et al., 1988; cf. Robinson et al., 1989), streptococcal cellwall-induced arthritis (Sternberg et al., 1989), electroconvulsive shock (Herman et al., 1989), and restraint and swim stress (Harbuz and Lightman, 1989), are capable of increasing hypothalamic CRF mRNA. That such effects can occur in the face of presumably heightened negative-feedback influences of glucocorticoids associated with acute and chronic stress poses fundamental questions concerning the manner in which neural and hormonal influences may interact to regulate hypophysiotropic CRF expression. Although each of the stressors studied to date is known to activate the hypothalamo-pituitary-adrenal (HPA) axis, they also stimulate other afferent pathways concerned with pain, osmotic, metabolic, and immune-system regulation. Moreover, in none of these models have acute and chronic effects been compared, and little is known as to how stress may influence CRF expression in extrahypothalamic cell groups. Thus, despite several lines of evidence to suggest that "stress" induces CRF mRNA accumulation in the hypothalamus, the time course and regional specificity of the effects of stress on CRF gene expression remain to be rigorously defined.

We have used electrical footshock, an established and readily controlled stressor (Kant et al., 1983; Rivier and Vale, 1987), as a model with which to compare acute and chronic effects of stress on CRF mRNA expression in the central limb of the HPA axis, and in extrahypothalamic cell groups. In addition to the PVN, we focused our analyses on the olfactory bulb and Barrington's nucleus. We have recently described high concentrations of CRF immunoreactivity and mRNA in the olfactory bulb (Imaki et al., 1989), which may be viewed here as representing a site of CRF expression in a sensory (ostensibly nonstress-related) system. Barrington's nucleus, recognized as a pontine micturition center that projects to parasympathetic preganglionic neurons in the sacral spinal cord, harbors a prominent group of CRF-immunoreactive cells and may be viewed as a representative of sites of CRF expression in central autonomic cell groups.

\section{Materials and Methods}

Adult male Sprague-Dawley albino rats $(200-250 \mathrm{gm})$ were used in all experiments. Animals were housed 3-6 per cage in a room with controlled temperature and a fixed lighting schedule (lights on from 6:00 A.M. to 6:00 P.M.). Food and water were given ad libitum. The rats were divided into 3 groups; control, shocked, and sham handling. The control group was kept in a separate room from the others and received no treatment. After a 1-week adaptation period, the shock group was transported to the experimental room, and each rat was placed in a shock cage. Scrambled inescapable electroshocks were delivered by Coulbourn shockers (Coulbourn Instruments, Lehigh Valley, PA) to the grid floors of Plexiglas chambers $(30 \times 20 \times 30 \mathrm{~cm})$. A program run on an Apple $2 \mathrm{E}$ computer was used to enter the shock regimen. In the acute stress paradigm, $30 \mathrm{~min}$ of intermittent footshocks $(1.5 \mathrm{~mA}, 1 \mathrm{sec}$ duration, administered 60 times randomly over $30 \mathrm{~min}$ ) were applied between 9:00 A.M. and 9:30 A.M., and the rats were killed 2, 4, 12 , and $24 \mathrm{hr}$ after the end of the footshock session. For chronic stress, the same shock regimen was applied twice daily at random up to $7 \mathrm{~d}$, and the rats were killed between 1:00 P.M. and 3:00 P.M. on the next day following the final footshock session. In the sham-handling group, rats were manipulated in the same manner but did not experience footshock stress. To avoid contact between the shocked and the sham-handling group, the experiments were carried out in a separate room, and the shock cages used for the shocked group were never used for the shamhandling group.

The footshock stress paradigm was modeled after one described by Holt et al. (1986), though, for humane reasons, the current amplitude and shock frequency were reduced. Animals subjected to footshock responded typically by displaying startle or jumping responses. Chronically stressed rats lost a moderate amount of body weight ( $7 \%$ of control values over $7 \mathrm{~d}$ ), but displayed no other overt physical or behavioral signs that would distinguish them from controls. We employed mild footshock as a stress model on the basis of its reproducibility and the ease with which the effects of acute and chronic exposure could be compared.

In separate groups of animals, adrenalectomy (ADX) was performed under ether anesthesia via a dorsal approach. Sham operations were performed by manipulating the animal in the same manner but without removal of the adrenal glands. One group of rats received a replacement dose $(100 \mu \mathrm{g} /$ rat, s.c.) of dexamethasone for $5 \mathrm{~d}$, beginning at 2 weeks after ADX surgery. All rats were killed 2 or 3 weeks after treatment.

Northern blot analysis. Brains were obtained by decapitation and regionally dissected by the method of Glowinski and Iverson (1966). Becausc CRF mRNA was not detected in Northern blot of the striatum, hippocampus, and cerebellum (T. Imaki and W. Vale, unpublished observations), only 5 brain regions, the olfactory bulb, cerebral cortex, midbrain (including thalamus), hypothalamus, and brain stem (medulla oblongata and pons), were taken. The tissues were stored at $-70^{\circ} \mathrm{C}$ until RNA extraction. Total RNA was isolated by the acid guanidium-thiocyanate-phenol-chloroform method (Chomczynski and Sacchi, 1987). Total RNAs $(20 \mu \mathrm{g})$ were denatured in $2.2 \mathrm{M}$ formaldehyde and subjected to electrophoresis on a $1.2 \%$ agarose formaldehyde gel in $20 \mathrm{~mm}$ morpholinopropanesulfonic acid (MOPS) ( $\mathrm{pH}, 7.0), 5 \mathrm{~mm}$ sodium acetate, and $1 \mathrm{~mm}$ EDTA. After electrophoresis, RNA was transferred to a Hybond $\mathrm{N}$ filter (Amersham) and UV crosslinked. The RNA blot was then incubated at $65^{\circ} \mathrm{C}$ for $4 \mathrm{hr}$ in prehybridization buffer containing 5 $\times$ SSPE (1 SSPE: $0.01 \mathrm{~m}$ phosphate buffer, $\mathrm{pH} 7.0 / 0.15 \mathrm{M} \mathrm{NaCl}$ ) $10 \times$ Denhart's solution $(0.02 \%$, w/v, each of bovine serum albumin, Ficoll 400 , and polyvinylpyrrolidone), $50 \%$ formamide, $0.5 \%$ sodium dodecyl sulfate (SDS), and $500 \mu \mathrm{g} / \mathrm{ml}$ denatured salmon-sperm DNA. Hybridization was carried out with a prepro-CRF cRNA probe labeled with $\left(\alpha-{ }^{32} \mathrm{P}\right) \mathrm{GTP}$ at $65^{\circ} \mathrm{C}$ in the same buffer overnight. Washings were performed successively in $1 \times \mathrm{SSPE} / 0.1 \% \mathrm{SDS}, 0.1 \times \mathrm{SSPE} / 0.1 \% \mathrm{SDS}$, and $0.1 \times \mathrm{SSPE}$ at $65^{\circ} \mathrm{C}$. Dried filters were autoradiographed at $-70^{\circ} \mathrm{C}$ with an intensified screen for 1-3 d, and films were developed. Autoradiographic mRNA signals were quantified using a Hoefer scanning densitometer. To obtain accurate RNA measurements, hybridization with chicken $\beta$-actin probe was performed as an internal standard. The ratio of CRF : actin hybridization was calculated to estimate the levels of CRF mRNA following each treatment. All data were measured within the linear range of detection. 


\section{HYPOTHALAMUS}

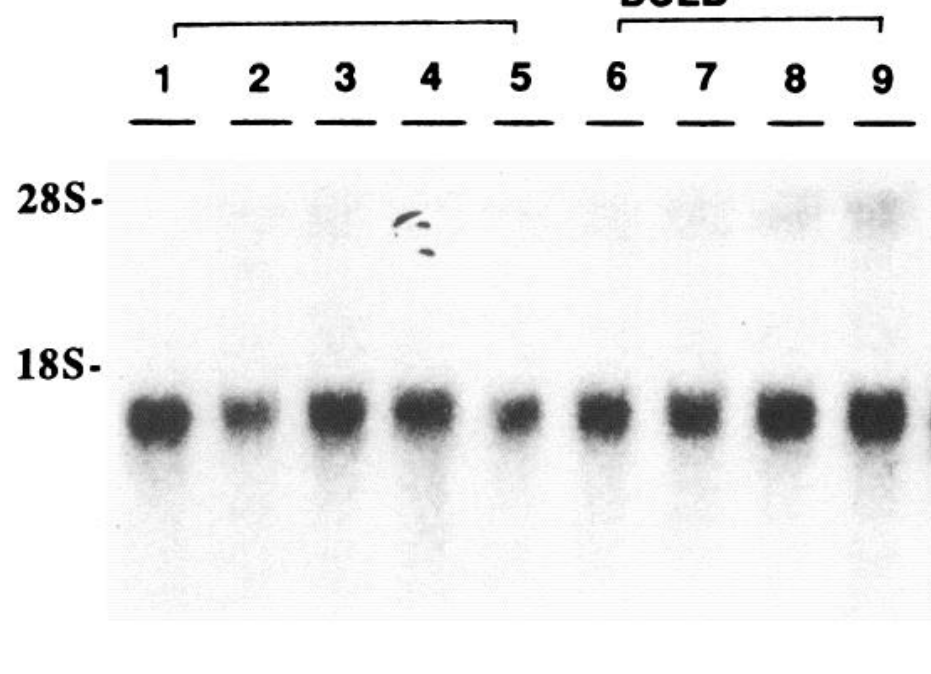

\section{BRAINSTEM}

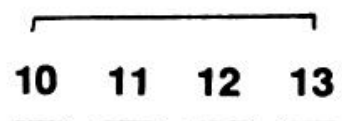

$1011 \div$

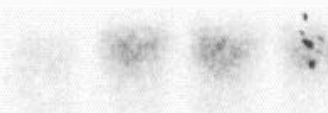

Figure 1. Northern blot analysis of effects of ADX and dexamethasone replacement on CRF mRNA levels in hypothalamus, olfactory bulb, and brain stem. Lane 1: hypothalamus polyA ${ }^{+}$ RNA, $1.25 \mu \mathrm{g}$; lanes 2-5: hypothalamus total RNA, $20 \mu \mathrm{g}$; lanes 6-9: olfactory bulb total RNA, $20 \mu \mathrm{g}$; lanes 10-13: brain stem total RNA, $20 \mu \mathrm{g}$. Lanes 2, 6, and 10: sham group; lanes 3,7 , and 11: 2 weeks after ADX; lanes 4, 8, and 12: 3 weeks after ADX; lanes 5, 9, and 13: ADX + dexamethasone replacement. Exposure time was $3 \mathrm{~d}$. $28 S$ and $18 S$ represent the position of $28 \mathrm{~S}$ and $18 \mathrm{~S}$ ribosomal RNAs, respectively.
In situ hybridization. Rats were deeply anesthetized and perfused with $4 \%$ paraformaldehyde in a 2 -step procedure in which the $\mathrm{pH}$ of fixative is varied over the course of the perfusion (Swanson et al., 1983). Brains were placed overnight at $4^{\circ} \mathrm{C}$ in fixative with $10 \%$ sucrose added. Frozen sections ( $20 \mu \mathrm{m}$ for hypothalamus, $30 \mu \mathrm{m}$ for olfactory bulb and brain stem) were cut on a siding microtome, mounted onto gelatin- and polyL-lysine-coated slides, and air dried.

The hybridization protocol was similar to those described previously (Imaki et al., 1989; Simmons et al., 1989). Prior to hybridization, sections were dried under vacuum for overnight and digested by proteinase $\mathrm{K}\left(10 \mu \mathrm{g} / \mathrm{ml}, 37^{\circ} \mathrm{C}, 30 \mathrm{~min}\right)$, acetylated, and dehydrated. After vacuum drying, $100 \mu$ l hybridization mixture $\left(10^{6} \mathrm{cpm} / \mathrm{ml}\right)$ with $10 \mathrm{~mm}$ of dithiothreitol (DTT) was spotted on each slide, sealed under a coverslip, and incubated at $55^{\circ} \mathrm{C}$ overnight. The coverslips were then removed, and the slides were rinsed in $4 \times \mathrm{SSC}$ at room temperature. They were digested by RNAase A $\left(20 \mu \mathrm{g} / \mathrm{ml}, 37^{\circ} \mathrm{C}, 30 \mathrm{~min}\right)$, washed in $0.1 \times \mathrm{SSC}$ for $30 \mathrm{~min}$ at $55^{\circ} \mathrm{C}(1 \mathrm{SSC}: 15 \mathrm{~mm}$ trisodium citrate buffer, $\mathrm{pH} 7.0 / 0.15$ $\mathrm{M} \mathrm{NaCl}$ ). These sections were exposed at $4^{\circ} \mathrm{C}$ to $\mathrm{x}$-ray film for $2-7 \mathrm{~d}$, then dipped in NBT3 nuclear emulsion (1:1 with water; Kodak), exposed for $4 \mathrm{~d}$ to 5 weeks, and developed. The slides were counterstained with thionin. An adjoining series of sections was stained with thionin to provide better cytoarchitectonic definition for analysis. All samples from a single experiment were run in a single assay.

Quantification of in situ hybridization. All quantification was done in nuclear-emulsion-dipped slides. In the case of the PVN, the sections containing the dorsal aspect of the medial parvocellular subdivision of the nucleus (Swanson et al., 1983), where hypophysiotropic CRF cells are concentrated, were identified in thionin-stained reference sections. Corresponding sections in adjoining series of hybridization histochemical material were identified, and, using fiduciary marks in the Nissl material (the top and ependymal lining of the third ventricle and the neighboring borders of the immediately adjoining dorsal parvocellular, periventricular, and posterior magnocellular subdivisions of the PVN), an eyepiece reticle was positioned over the dorsal medial parvocellular $\mathrm{PVN}$ in the hybridized material. All the grains within the grid area (250 $\times 250 \mu \mathrm{m}$ ) were counted under bright-field illumination at $400 \times$ magnification. In most cases, almost all the silver grains in the parvocellular PVN labeled with CRF probe were distributed within the grid area. Backgrounds were determined by counting the grains over deep layers of cerebral cortex. These background values were then subtracted from the grain densities measured in the PVIN. For Barrington's nucleus, the in situ sections in which both Barrington's nucleus and the lateral parabrachial nucleus were clearly labeled with the CRF probe were noted. In most cases, 3 or 4 sections were obtained in each animal. CRF mRNA containing cells were counted at a magnification of $400 \times$ and were considered labeled when the density of the silver grains within a grid area $(25 \times 25 \mu \mathrm{m})$ exceeded $5 \times$ background levels, which, in these experiments, typically ranged between 4 and 5 grains/grid. Cells were counted bilaterally. Consequently, at least 6 areas were determined in each rat. The number of grains per cell falling within an area of the grid
$(25 \times 25 \mu \mathrm{m})$ and the number of grains over Barrington's nucleus were also determined under microscope $(400 \times)$ using a calibrated ocular grid in the bright-field view. In the case of olfactory bulb, the number of labeled cells and the number of grains per cell were counted as described above. Because the olfactory bulb is a relatively homogeneous structure, measurements were made in the areas distributed near the midrostrocaudal extent of the bulb.

Probe labeling. Prepro-CRF cRNA probe and $\beta$-actin $\mathrm{cRNA}$ probe were synthesized by SP- 6 polymerase. The pGEM- 4 plasmid containing the rat CRF and the pGEM-3 plasmid containing chicken $\beta$-actin cDNA insert were linearized with Hind III and EcoRI, respectively. Radioactive cRNA copies were synthesized by incubation of $36 \mathrm{~mm}$ Tris $(\mathrm{pH}$, 7.5), $0.1 \mu \mathrm{g}$ linearized plasmid in $6 \mathrm{mM} \mathrm{MgCl}_{2}, 2 \mathrm{~mm}$ spermidine, $8 \mathrm{~mm}$ DTT, $25 \mathrm{~mm}$ UTP/GTP/CTP, $5 \mu \mathrm{m}$ unlabeled GTP, $\left(\alpha^{-{ }^{32}}\right.$ P)GTP for Northern blot or $\left(\alpha{ }^{-35}\right)$ GTP for in situ hybridization, 1 U RNAsin (Promega), and $10 \mathrm{U} \mathrm{SP6}$ polymerase (Promega) for $60 \mathrm{~min}$ at $37^{\circ} \mathrm{C}$. The specific activity of the probe was about $1.0 \times 10^{8} \mathrm{dpm} / \mu \mathrm{g}$. As a control for nonspecific labeling, a sense CRF probe (same sequence as CRF mRNA) generated by $\mathrm{T} 7$ polymerase was used on some adjacent sections from experimental animals, and no specific signal was detected.

Data analysis. Results are presented as means \pm SEM throughout. Statistical significance was determined by 1-way analysis of variance followed by the Duncan's multiple range test. Single comparisons were made by the Mann-Whitney $U$ test. Criteria for significance was set at $P<0.05$.

\section{Results}

\section{Effect of manipulation of glucocorticoid status}

Northern blot analysis showed the relative regional levels of CRF mRNA in intact animals to be brain stem $>$ olfactory bulb $>$ hypothalamus $>$ midbrain $>$ cerebral cortex, and the size of CRF mRNA (1.4 kb) was the same in these areas (Fig. 1; data on cortex and midbrain not shown). Two weeks after ADX, CRF mRNA in the whole hypothalamus increased to $160 \%$ of control values, and this effect was reversed by dexamethasone replacement (Fig. 1). In contrast to the hypothalamus, neither ADX nor dexamethasone replacement affected CRF mRNA levels in the other 4 brain regions sampled (Fig. 1).

A dark-field photomicrograph of CRF mRNA hybridization in the pontine tegmentum and an adjacent section stained with thionin are shown in Figure 2. CRF mRNA was expressed prominently in Barrington's nucleus. It should be noted that mRNA was strictly localized within Barrington's nucleus, and no specific hybridization signal with an antisense CRF probe was seen in the locus coeruleus or in the immediately adjoining regions 

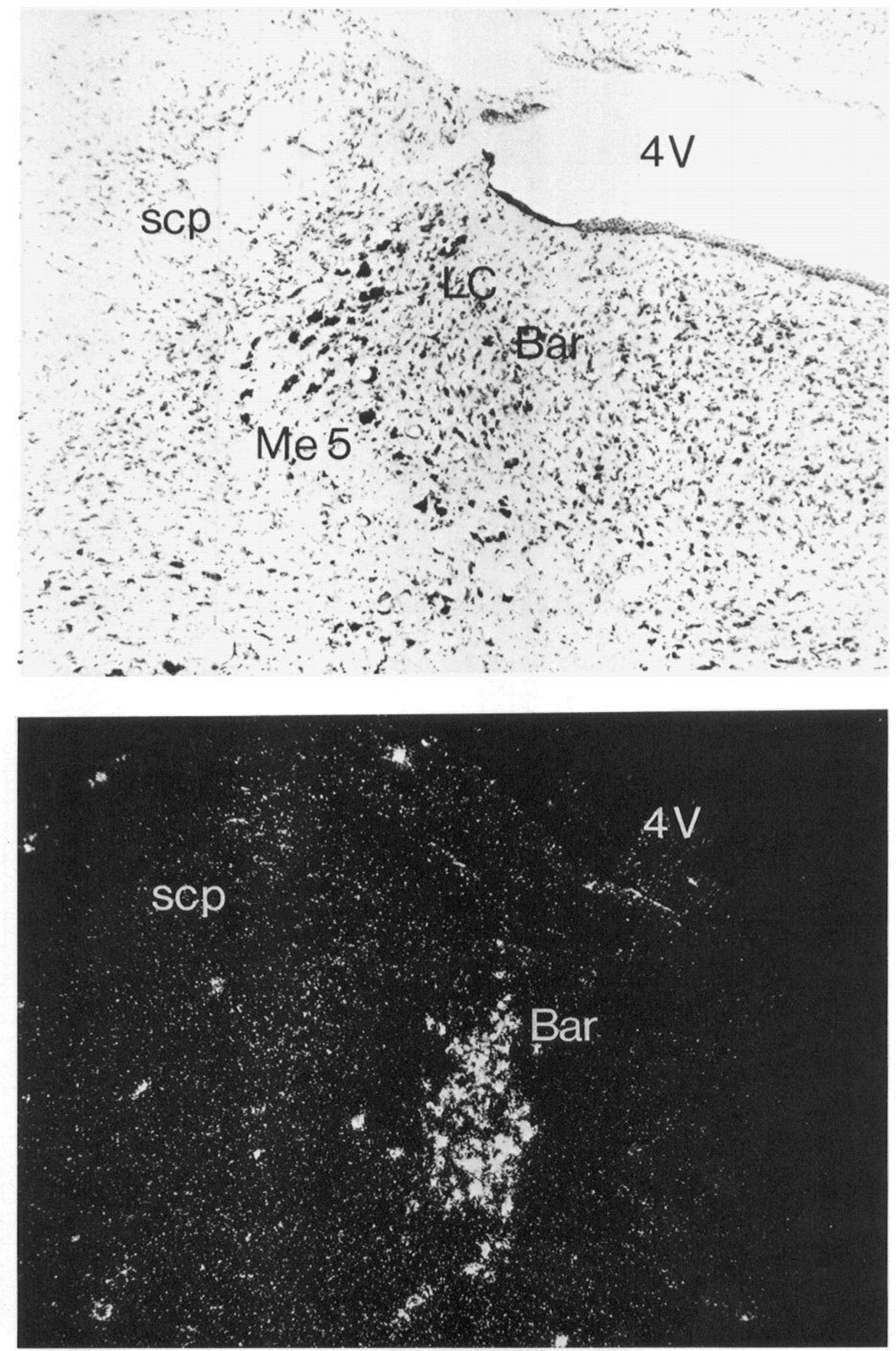

Figure 2. Adjacent coronal sections of dorsolateral pontine tegmentum showing localization of CRF mRNA signal in Barrington's nucleus. Top, A thionin-stained reference section showing cellular architecture of the region. Bottom, Dark-field photomicrograph $(260 \times)$ showing hybridization histochemical localization of a ${ }^{35} \mathrm{~S}$-labeled antisense cRNA probe. Positive signal was localized to Barrington's nucleus and not in the locus coeruleus. $4 V$, 4th ventricle; $L C$, locus coeruleus; Bar, Barrington's nucleus; $M e 5$, mesencephalic trigeminal nucleus; $s c p$, superior cerebellar peduncle. 

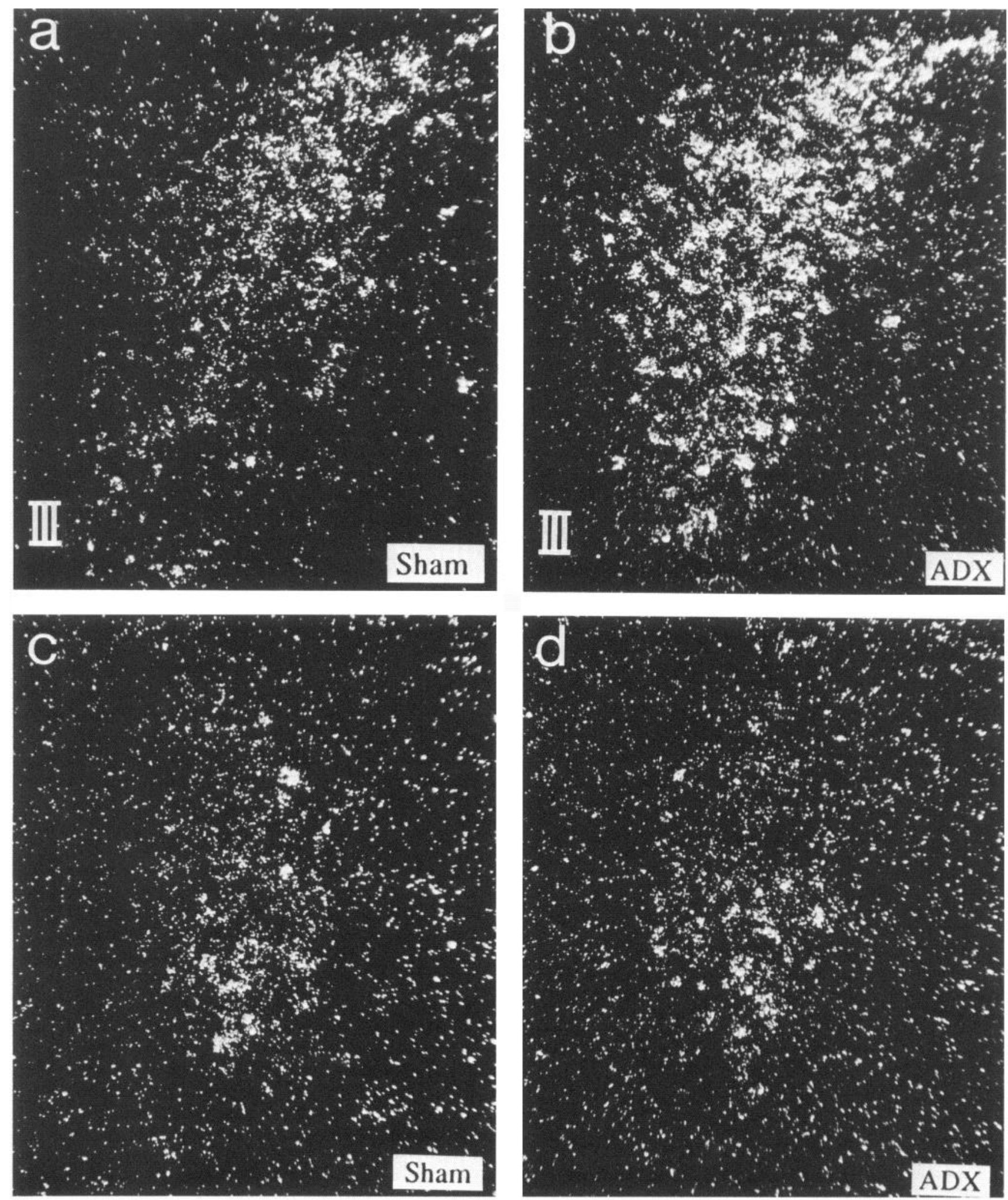

Figure 3. Dark-field photomicrographs (450x) to illustrate effects of ADX on CRF mRNA levels in PVN and Barrington's nucleus. Panels a and $b$ show a comparable level through the medial parvocellular part of the PVN taken from animals killed 2 weeks after sham operation $(a)$ or ADX $(b)$. Panels $c$ and $d$ show a similar comparison for Barrington's nucleus. Exposure time was $4 \mathrm{~d}$ in the PVN and $8 \mathrm{~d}$ in Barrington's nucleus. III, 3rd ventricle. 


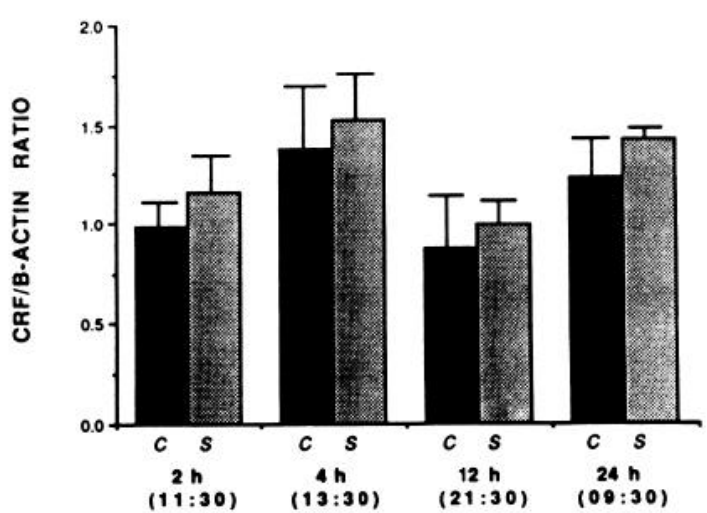

Figure 4. Northern blot analysis of effect of acute footshock stress on CRF mRNA levels in hypothalamus. Total RNAs $(20 \mu \mathrm{g})$ extracted from the hypothalami of rats killed at $2,4,12$, or $24 \mathrm{hr}$ following a single episode of footshock stress were hybridized with antisense CRF probe. Each value represents the mean \pm SEM of 3 determinations in each group. $C$ and $S$ represent control and shocked group, respectively. The clock times of death are shown in parentheses under the abcissa.

of the dorsal tegmentum. There was also no specific hybridization signal in the locus coeruleus at more caudal levels, where this cell group is more prominent (data not shown). In the PVN, ADX induced a marked increase in CRF mRNA to $285 \pm 49 \%$ of control grain-density values, but had no significant effect on either the number of positively hybridized cells or the grain density per cell in Barrington's nucleus $(P>0.05$; Fig. 3$)$.

\section{Effects of acute stress}

Northern blot analysis indicated that levels of CRF mRNA in the whole hypothalamus did not change significantly at any time point sample during the $24 \mathrm{hr}$ following a single session of stress (Fig. 4). Even in this coarsely dissected material, the underlying diurnal rhythm in levels of CRF mRNA expression in the PVN (high around midday, low at night; Watts and Swanson, 1989) was evident, and acute stress did not alter the rhythm. In contrast, acute footshock stress produced a decrease in CRF mRNA levels in the olfactory bulb (Fig. $5 a, b$ ). CRF mRNA content of the bulb began a steady decline at $4 \mathrm{hr}$ after stress and fell to levels significantly below control at $24 \mathrm{hr}(69.2 \pm 1.9 \%$ of control, $P<0.05)$. The size of CRF mRNA did not change $(1.4$ $\mathrm{kb}$ ) during the course of the treatment. It is noteworthy, however, that CRF mRNA levels in the olfactory bulb of the shamhandling group also declined, and at $24 \mathrm{hr}$ poststress, there was no significant difference between the sham and the shocked group (Fig. $5 c$ ). No significant differences in CRF mRNA levels in the midbrain, cortex, and brain stem were detectable by Northern blot analysis at any of the time points examined (data not shown).

Hybridization histochemical material revealed a marked ac-
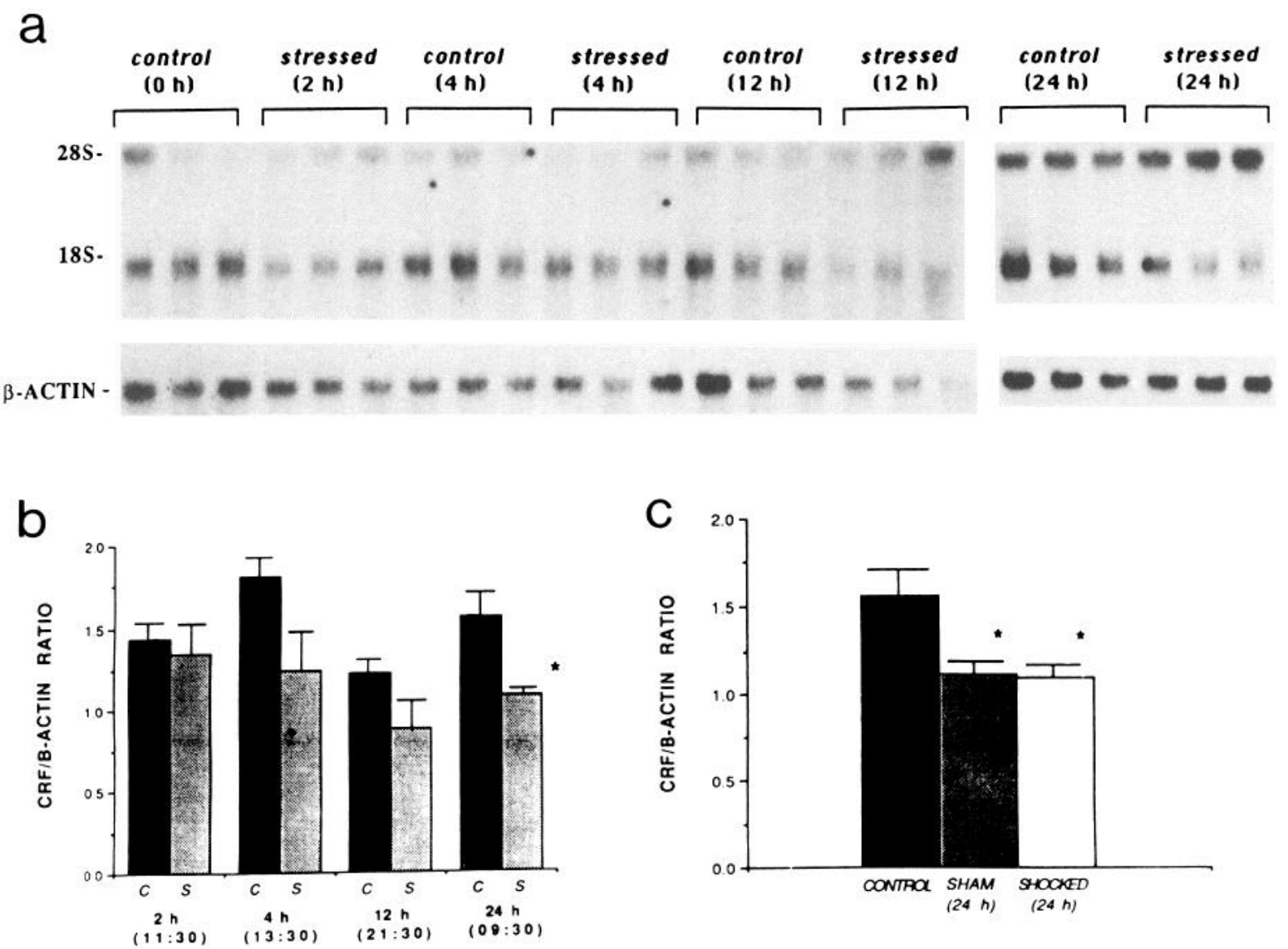

Figure 5. Northern blot analysis of effects of acute footshock stress and sham handling on CRF mRNA levels in whole olfactory bulb (a). Total RNAs $(20 \mu \mathrm{g})$ extracted from 1 olfactory bulb of animals killed at $2,4,12$, or $24 \mathrm{hr}$ after stress or sham handling were hybridized with antisense CRF cRNA probe. Three animals were studied in each group. The exposure time was $3 \mathrm{~d}$. The bar graphs summarize densitometric data from the groups that received footshock stress $(b)$ or sham handling $(c)$. Each value is the mean \pm SEM of 3 animals in each group. $C$ and $S$ represent control and shocked group, respectively. ${ }^{*}, P<0.05$ vs. controls. 

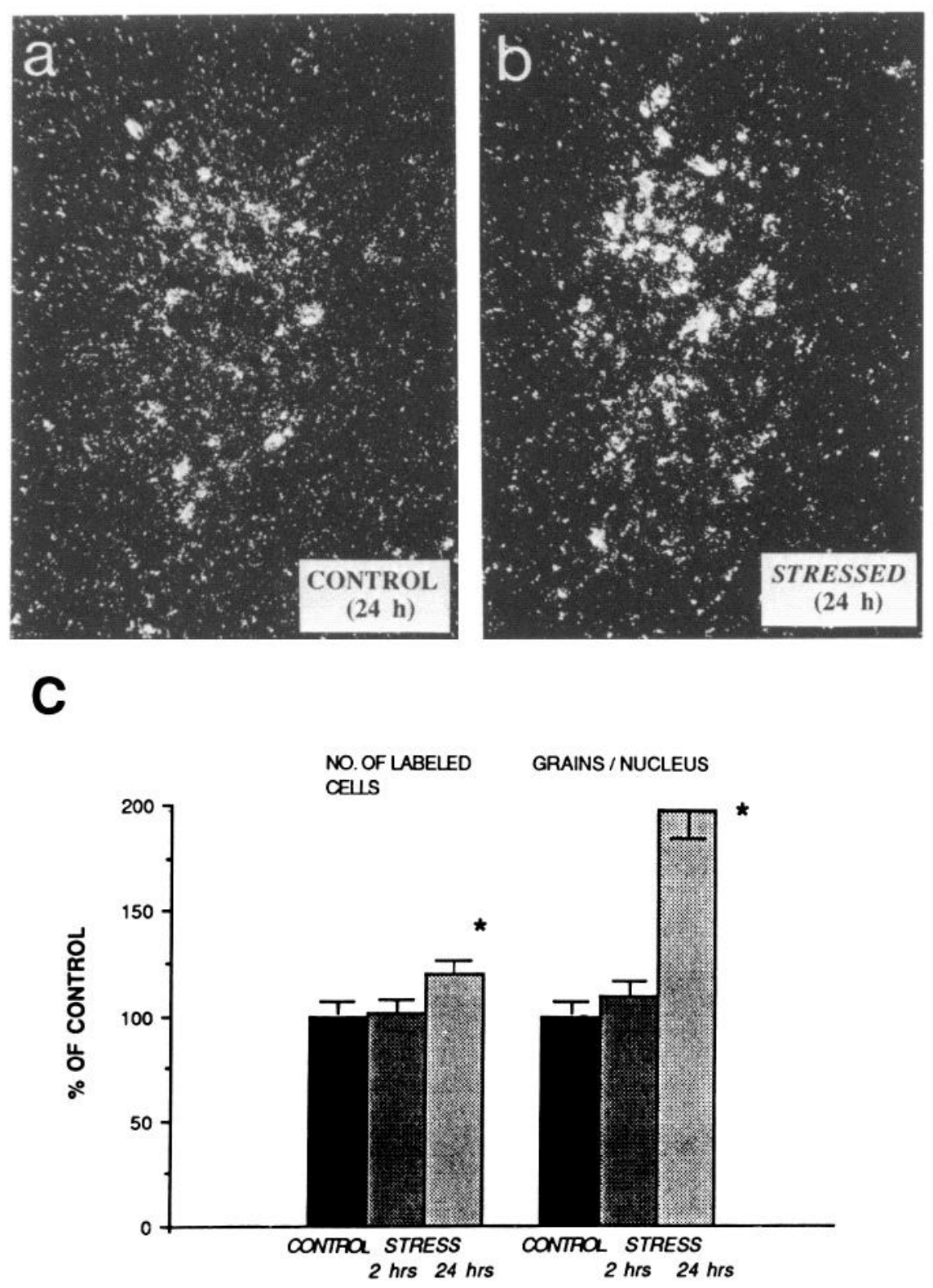

\begin{abstract}
Figure 6. Effects of acute stress on CRF mRNA in Barrington's nucleus. Panels $a$ and $b$ show dark-field photomicrographs $(300 \times)$ of hybridization signal at a comparable level through Barrington's nucleus from animals killed $24 \mathrm{hr}$ after control procedures $(a)$ or after a single session of footshock stress $(b)$. Note that CRF mRNA content in Barrington's nucleus increased after stress. Exposure time was $10 \mathrm{~d}$. The bar graphs (c) summarize the results of cell counts and grain density measures for Barrington's nucleus, from nonstressed (control) animals, and from groups killed at 2 or $24 \mathrm{hr}$ following stress. Each value is the mean \pm SEM of 12 (left) and 3 (right) determinations in each group. ${ }^{*}$, $P<0.05$ vs. controls.
\end{abstract}

cumulation of CRF mRNA signal in Barrington's nucleus at 24 hr after footshock stress (Fig. $6 a, b$ ). Significant increases in both the number of labeled cells and the number of grains per cell in Barrington's nucleus were observed $24 \mathrm{hr}$ after stress (number of labeled cells: $120 \pm 7 \%$ of control value, $P<0.05$; number of grains: $198 \pm 19 \%$ of control value, $P<0.05$; Fig. $6 c$ ). Figure $7, a$ and $b$, shows frequency-distribution histograms of grains per cell from 1 representative section through the midextent of Barrington's nucleus from rats in each group. Although the peaks of the control and stressed group distributions were similar, the number of cells that contained a greater number of grains $(>80)$ was clearly higher in the acutely stressed group (Fig. $7 b$ ) than control. The mean number of grains per cell was also higher in the stressed group, suggesting that acute stress produced an increase in mRNA levels in Barrington's nucleus.

In contrast, and in keeping with the results from Northern blots, there was no significant difference between CRF mRNA levels in the PVN of the shocked and control groups after acute stress (number of grains over the PVN $24 \mathrm{hr}$ after stress: 106.3 $\pm 8.6 \%$ of control value, $P>0.05$ ).

In the olfactory bulb, CRF mRNA was detected principally in mitral cells and in cells distributed throughout the external plexiform layer (presumably tufted cells; Fig. $8 a, b$ ), as previously reported (Imaki et al., 1989). Acute footshock stress produced a decrease in CRF mRNA signals over the mitral and tufted cells at $24 \mathrm{hr}$ (Fig. $8 a, b$ ). The number of mitral and tufted cells that met the criterion for positive labeling also significantly decreased after acute stress (Fig. $8 c$ ). Frequency distributions of grain density in mitral cells showed a downward shift in the peak of the distributions in the stressed group, such that only 1 cell was encountered that contained more than 90 grains per cell in the stressed group (Fig. $7 c, d$ ). Consequently, the mean number of grains per cell in the stressed group was significantly lower than that of controls (control, 109; stressed, 68; $P<0.05$ ), as was the number of cells showing a positive hybridization signal. Because the criterion employed for identifying a cell as 
a

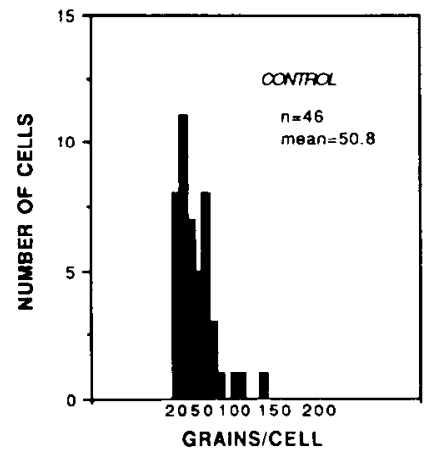

b

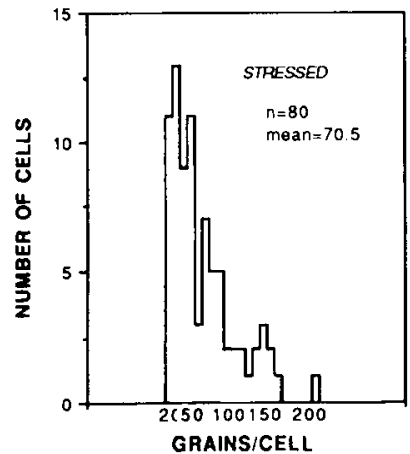

C

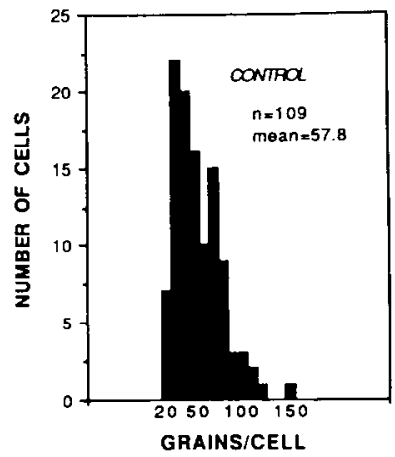

d

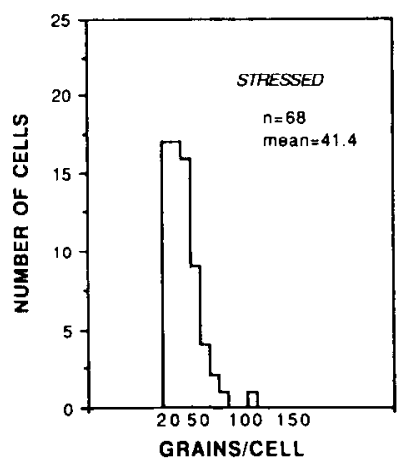

Figure 7. Frequency-distribution histogram to illustrate effects of acute stress on intensity of CRF mRNA signal in Barrington's nucleus $(a, b)$ and olfactory bulb $(c, d)$. Grain densities were generated by counting reduced silver grains overlying individual cclls in Barrington's nucleus and the mitral cell layer from sections taken through comparable levels of the nucleus from representative members of the control $(a, c)$ and stressed $(b, d)$ groups. The number of cells counted in each case $(n)$ and the mean value of grains per cell (mean) are indicated.

being positively hybridized was arbitrary, this does not necessarily imply that fewer cells in the olfactory bulb were expressing CRF mRNA.

\section{Effects of chronic stress}

Chronic intermittent footshock stress administered over 3 or 7 $\mathrm{d}$ produced an increase in CRF mRNA levels in the whole hypothalamus as measured by Northern blot analysis. After 7 d, hypothalamic mRNA levels reached $184 \pm 26 \%$ of control values $(P<0.05$; Fig. 9). The same stress regimen resulted in CRF mRNA levels in the olfactory bulb that declined to 54.1 $\pm 5.1 \%$ of control values after $7 \mathrm{~d}(P<0.05$; Fig. 9). However, as was the case in the acute stress experiment, a comparable decrease in CRF mRNA levels in the olfactory bulb was seen in the sham-handling group (Fig. 10). Sham handling did not induce significant changes in CRF mRNA levels in the hypothalamus as compared to controls (Fig. 10). No significant changes in CRF mRNA levels were detected in the brain stem, midbrain (Fig. 9), or cerebral cortex (data not shown) after chronic intermittent footshock stress.

Hybridization histochemical material revealed an increased accumulation of silver grains over the medial parvocellular part of the PVN and over Barrington's nucleus following chronic intermittent footshock stress (Fig. 11). The relative changes in grain density after stress were to $182 \pm 24 \%$ (3-d stress, $P<$ $0.05)$ and $197 \pm 29 \%$ (7-d stress, $P<0.05)$ of control values

in the PVN, and to $190 \perp 10 \%$ (3-d stress) and $165 \pm 25 \%(7-d$ stress) of control values in Barrington's nucleus (Fig. 12). The number of positively hybridized cells was also significantly increased after chronic stress in Barrington's nucleus (3-d: $166 \pm$ $8 \%$ of control, $P<0.05 ; 7$-d: $155 \pm 6 \%$ of control, $P<0.05$ ). Frequency distribution of grains per cell in Barrington's nucleus was virtually identical to that seen following acute stress (Fig. $13 c, d)$; that is, both the proportion of cells overlain by high grain densities and the mean number of grains per cell was greater in the chronically stressed group than in controls.

In the olfactory bulb, CRF mRNA signals were also decreased after 7-d stress (Fig. 14a). A significant reduction in the number of cells labeled with the CRF probe was observed in both mitral and tufted cells after 7-d stress (Fig. 14b). The frequency distribution of the CRF mRNA signal in mitral cells showed a pattern similar to that seen following acute stress experiments (Fig. 13a,b). Therc was no cell containing more than 70 grains per cell in the stressed group, and the mean value of number of grains per cell was significantly lower in the stressed group (27.6) than that in controls (44.0). The number of cells displaying a positive hybridization signal (more than 20 grains per cell) was also lower in the stressed group than in controls.

\section{Discussion}

The results of the present study provide an indication of the time course and regional specificity of the effects of stress on levels of CRF mRNA in the rat brain. We have used Northern blot and hybridization histochemical analyses to show that chronic, but not acute, exposure to footshock stress increases CRF mRNA levels in the whole hypothalamus and in the PVN, the acknowledged seat of neurons that provide the final common path for eliciting the pituitary-adrenal response to stress. Other prominent sites of CRF expression were responsive in both the acute and the chronic stress paradigms, with mRNA levels being up-regulated in Barrington's nucleus and down-regulated in the olfactory bulb. The PVN, however, was unique among these loci in that it was the sole site at which CRF mRNA was perturbed by stress and manipulation of steroid hormone status.

Previous studies measuring hypothalamic CRF peptide content suggested that both $\mathrm{CRF}$ release and biosynthesis were increased after stress. For example, Suemaru et al. (1985) showed by radioimmunoassay that hypothalamic CRF-like immunoreactivity (CRF-LI) was reduced at $15 \mathrm{~min}$, and elevated at 180 min, after the start of a cold restraint stress. Moldow et al. (1986) reported that CRF-LI levels in the hypothalamus were decreased 15 and 30 min after the start of restraint stress, which was followed by a significant increase at $60 \mathrm{~min}$ that was abolished by pretreatment with protein synthesis inhibitor. These data were interpreted to suggest that hypothalamic CRF biosynthesis increased after stress. Given the fact that CRF content may be affected by changing rates of synthesis, transport, secretion, and degradation, results of this type are suggestive, at best.

Tissue levels of CRF mRNA should provide a reasonable reflection of CRF biosynthesis, though it cannot be determined from assays of mRNA levels alone whether alterations may be indicative of changes in CRF gene transcription and/or processing and/or degradation of mRNA. In this study, we demonstrated that CRF mRNA levels increased in the hypothalamus by Northern blot after chronic stress, and in situ hybridization clearly showed that this increase occurred mainly in the parvocellular division of the PVN. These results suggest 

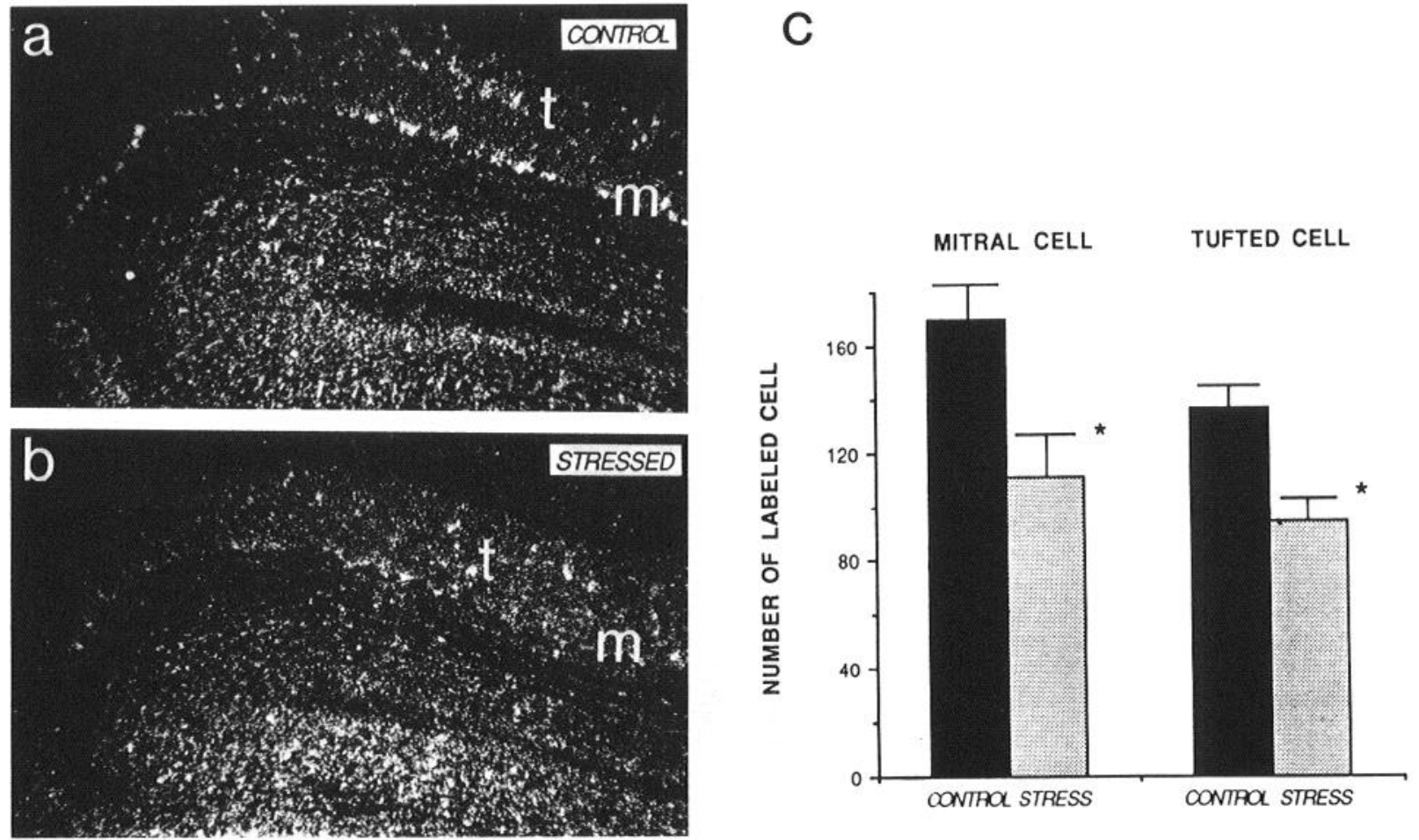

Figure 8. Effects of acute stress on CRF mRNA in olfactory bulb. Dark-field photomicrographs $(160 \times)$ are of autoradiograms from coronal sections through the olfactory bulb from representative control $(a)$ and 24-hr-stressed $(b)$ rats hybridized with antisense CRF probe. CRF mRNA was detected mainly over mitral cells $(m)$ and in the external plexiform layer, which presumably represent tufted cells $(t)$. Note that the strength of the CRF mRNA signal in both cell types decreased after stress. Exposure time was $11 \mathrm{~d}$. Panel $c$ shows a bar graph summarizing the effects of acute stress on the number of labeled mitral (left) and tufted (right) cells positively hybridized with CRF probe. Each value is the mean \pm SEM of 8 determinations in each group. ${ }^{*}, P<0.05$ vs. controls.

that chronic intermittent footshock stress stimulates CRF biosynthesis through accumulation of CRF mRNA.

Although it is clear from studies monitoring portal blood CRF levels that stressors such as hemorrhage can acutely stimulate secretion of CRF (Plotsky and Vale, 1984), we have not observed a footshock-stress-induced increase in CRF mRNA levels as analyzed by Northern blot and in situ hybridization. It is possible that there is a delay between the effects on secretion and on biosynthesis. Alternatively, a long half-life and a large pool of CRF mRNA might make it difficult to detect changes in mRNA levels after acute stress. The half-life of mRNAs encoding most secretory peptides is relatively long, and neurosecretory cells contain substantial pools of cytoplasmic mRNA (Fremeau et al., 1986). Perhaps the most likely explanation for
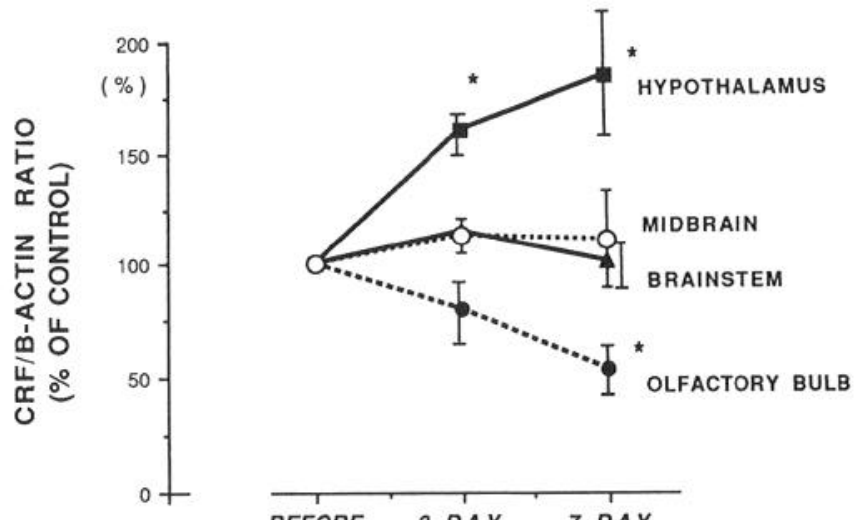

BEFORE

3-DAY

7.DAY

Figure 9. Effects of chronic stress on CRF mRNA levels in whole hypothalamus (squares), olfactory bulb (solid circles), brain stem (triangles), and midbrain (open circles). The graph summarizes densitometric data from Northern blot analysis of effects of chronic (3- and 7-d) stress. The values (mean \pm SEM) are based on results from 3 animals killed at each time point. ${ }^{*}, P<0.05$ vs. controls.

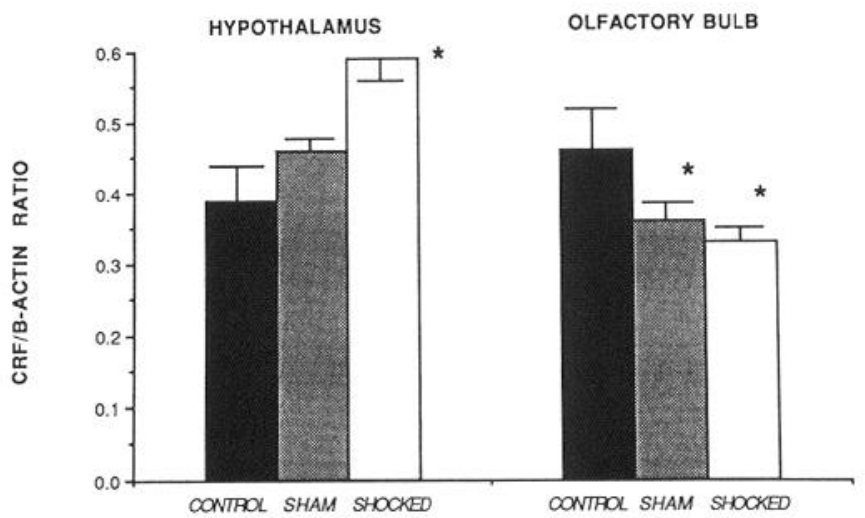

Figure 10. Effects of chronic footshock stress and sham handling on levels of CRF mRNA in whole hypothalamus (left $)$ and olfactory bulb (right). Each value represents the mean \pm SEM of 3 animals in each group and was derived from densitometric analysis of Northern blot hybridization. ${ }^{*}, P<0.05$ vs. controls. 

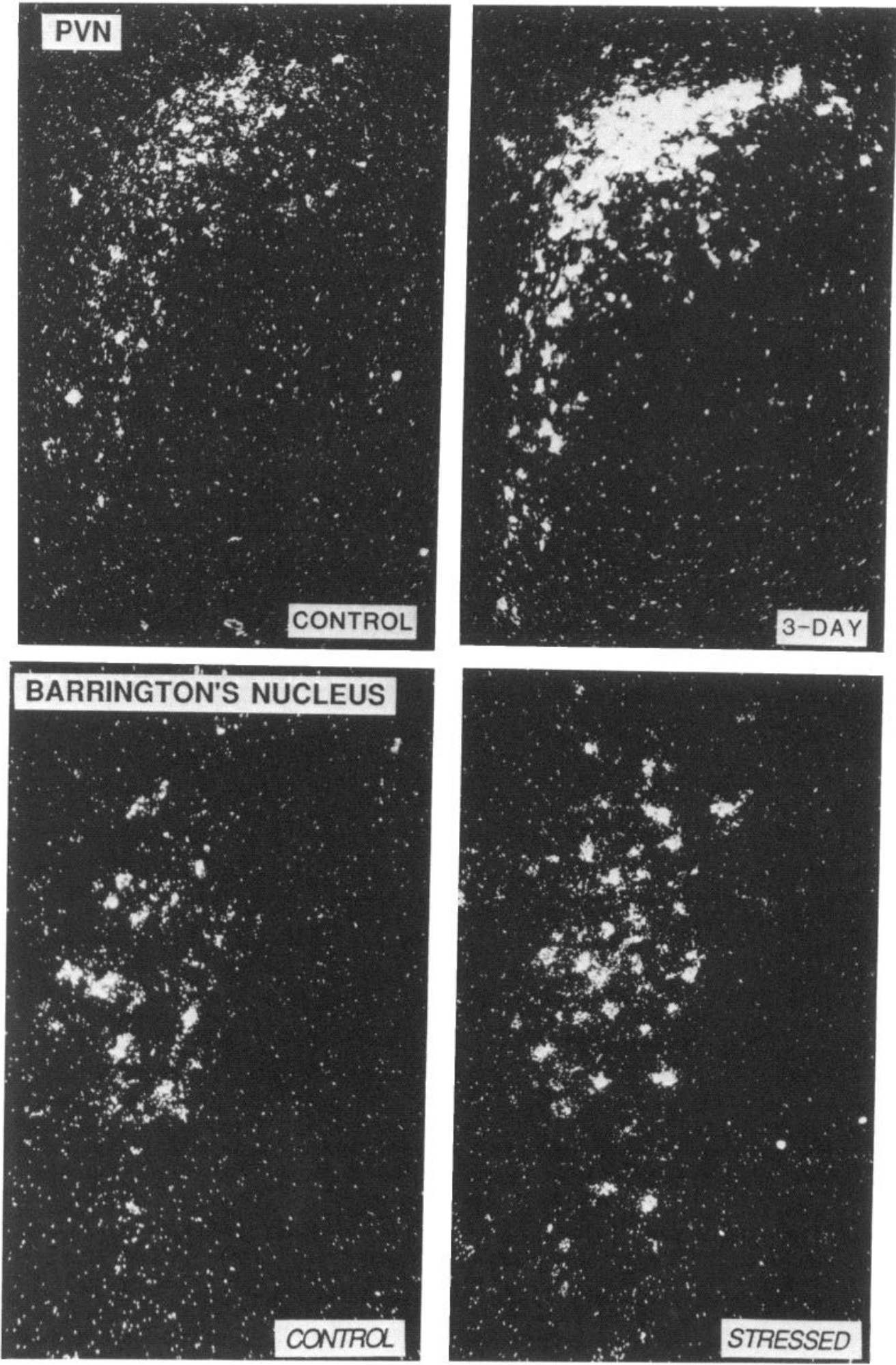

Figure 11. Chronic stress effects on CRF mRNA in PVN and Barrington's nucleus. Top, Dark-field photomicrographs $(300 \times)$ of hybridization histochemical material showing sections through comparable levels of the parvocellular PVN from control (left) and 3-d-stressed (right) rats. Bottom, A similar comparison seen in sections through comparable levels of Barrington's nucleus. Exposure time was $7 \mathrm{~d}$ for the $\mathrm{PVN}$ and $14 \mathrm{~d}$ for Barrington's nucleus.

our failure to detect acute effects in the PVN is that stressinduced accumulation of mRNA is blunted by presumably high glucorticoid titers that accompany this and other forms of stress.

Along these lines, our results with ADX and glucocorticoid replacement are in good agreement with previous reports (Jingami et al., 1985b; Young et al., 1986; Beyer et al., 1988; Swanson and Simmons, 1989), which have established glucocorti- coids as providing a potent inhibitory influence on CRF mRNA expression in the PVN. For example, Jingami et al. (1985b) described a $52 \%$ increase in hybridizable CRF mRNA in the whole hypothalamus at $7 \mathrm{~d}$ after ADX, while more substantial $(222 \%)$ increases have been reported by Young et al. (1986) in the PVN, using in situ hybridization. We found a $60 \%$ increase in the whole hypothalamus by Northern blot and a $185 \%$ in- 


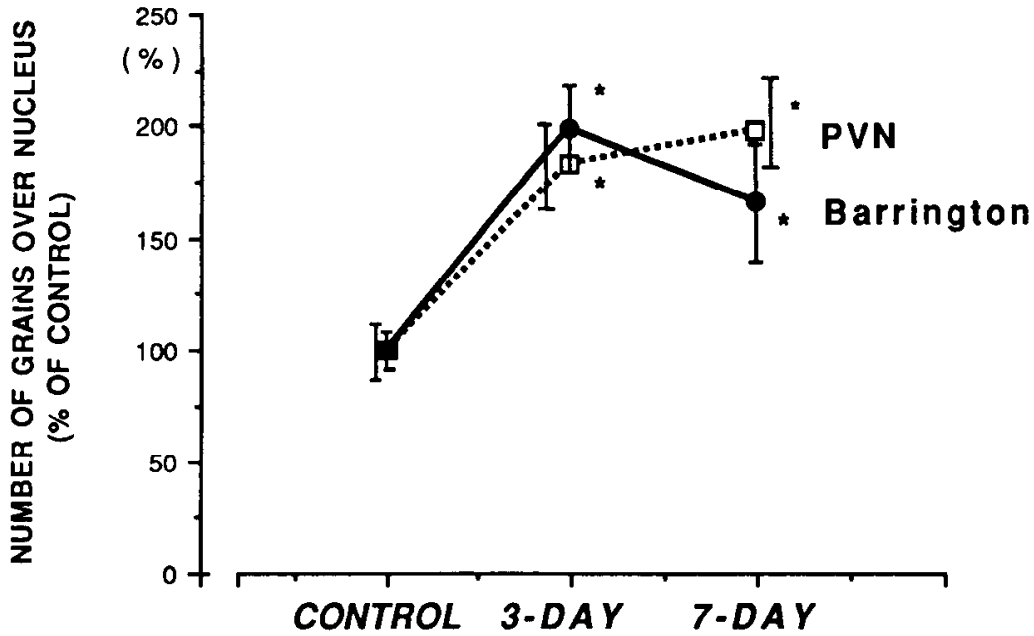

Figure 12. Summary of effects of chronic stress on CRF mRNA in PVN and Barrington's nucleus. The figure shows estimates of the change in the hybridization signal (grain density) over the parvocellular PVN (squares) and Barrington's nucleus (circles) after 3- or 7-d exposure to chronic footshock stress. Each value represents the mean \pm SEM of 3 determinations for each group and is expressed as a percentage of values obtained from untreated controls. ${ }^{*}, P$ $<0.05$ vs. controls.

crease in the PVN by in situ hybridization after ADX. Coupled with data to indicate that exposure of rats to footshock leads to elevated glucocorticoid levels (Allen et al., 1973), and wellestablished effects of exogenous glucocorticoids inhibiting hypothalamic CRF secretion (Plotsky and Vale, 1984; Suda et al., 1985; Plotsky et al., 1986) and mRNA expression, these data support the view that the stress-induced up-regulation of CRF mRNA expression in the PVN is partly mitigated by glucocorticoid feedback. The discrepancy between the estimates provided by Northern blot and in situ analyses of the post-ADX increment in CRF mRNA may well be attributable to the fact that CRF is known to be expressed in several hypothalamic cell types in addition to parvocellular neurosecretory neurons. The Northern blot analysis sampled additional cell types that may respond differentially (Swanson and Simmons, 1989) or not at all to perturbations in the steroid milieu, which would serve to dilute the estimated magnitude of the effect on the cell group of interest.

Recent data indicating that acute insulin-induced hypoglycemia fails to alter CRF mRNA levels in the whole hypothal- a

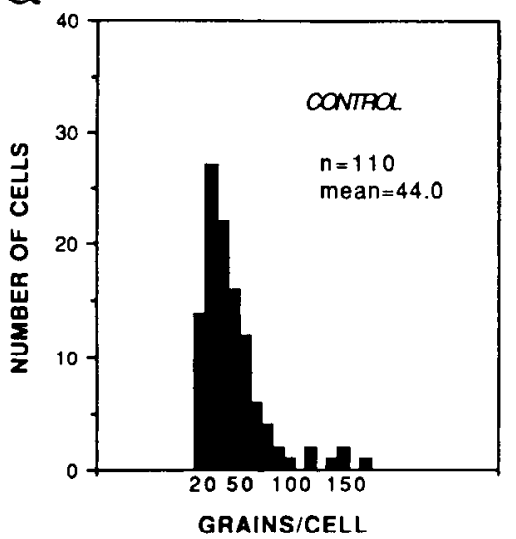

$b$

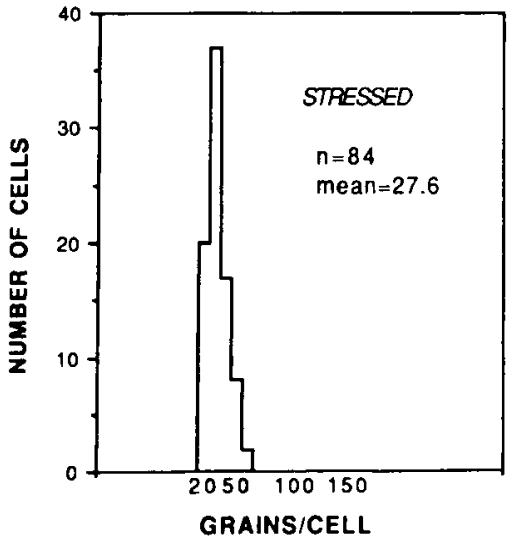

C

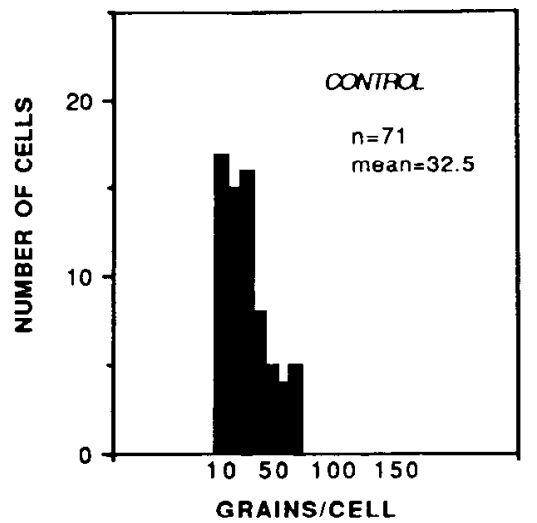

O

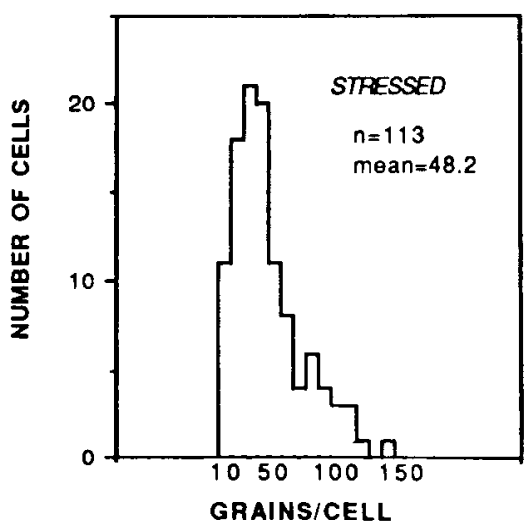

Figure 13. Frequency-distribution histogram to illustrate effects of chronic stress on intensity of CRF mRNA signal over Barrington's nucleus $(c, d)$ and mitral cell layer of olfactory bulb $(a, b)$. Grain densities were generated by counting reduced silver grains overlying individual cells in sections taken through comparable levels of Barrington's nucleus and the mitral cell layer from representative members of the control $(a, c)$ and stressed $(b, d)$ groups. The number of cells counted in each case $(n)$ and the mean value of grains per cell (mean) are indicated. 

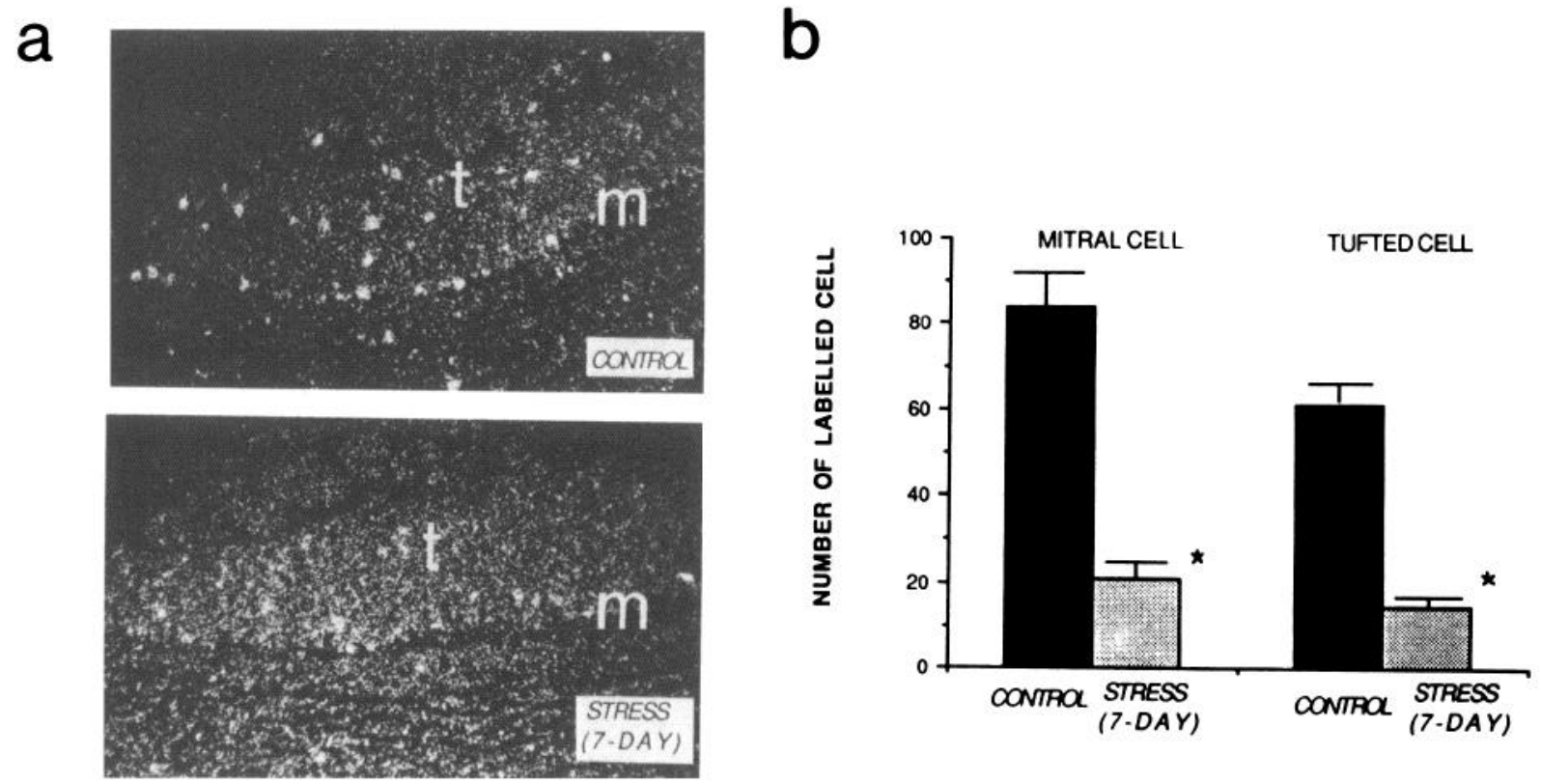

Figure 14. Effects of chronic stress on CRF mRNA in olfactory bulb. $a$, Dark-field photomicrographs $(200 \times)$ of hybridization histochemical material showing the distribution and strength of the CRF mRNA signal in the olfactory bulbs of control (upper panel) and 7-d-stressed (lower panel) animals. Note that CRF mRNA hybridizable signals in mitral $(m)$ and tufted cells $(t)$ both decreased after stress. Exposure time was 5 weeks. $b$, Effects of chronic stress on the number of labeled cells hybridized with antisense CRF probe in the mitral (left) and external plexiform (tufted) cell layers (right). Each value represents the mean \pm SEM of 8 determinations in each group. ${ }^{*}, P<0.05$ vs. controls.

amus or in micropunch samples of the PVN (Robinson et al., 1989) are consistent with our results. Others, however, have reported a hypoglycemia-induced 2 -fold increase in whole hypothalamic CRF mRNA levels within $30 \mathrm{~min}$ in anesthetized rats (Suda et al., 1988). Whether the use or avoidance of anesthesia could explain the differences between the results of these 2 studies remains to be determined. Nonetheless, several other acute stress paradigms, including hypertonic saline injection (Lightman and Young, 1989), restraint, forced swimming (Harbuz and Lightman, 1989), and streptococcal cell-wall-induced arthritis (Sternberg et al., 1989), have all been recently reported to produce a significant increase in hypothalamic CRF mRNA levels within several hours. Although it is difficult to explain the discrepancies between these and the present data, differences in the intensity and/or persistence of the stressors, and the likelihood that the effects are mediated via different pathways and hypothalamic neurotransmitter systems, would seem likely bases. Electrical footshock stress is considered a so-called neurogenic stress, which requires the integrity of the PNS, spinal cord, and other parts of the CNS to activate the hypothalamo-pituitary-adrenal axis (Greer et al., 1970; Allen et al., 1973). In contrast, the other challenges cited above are classified, at least in part, as systemic stressors, in which hormonal mechanisms are presumably dominant in mediating effects on hypothalamopituitary-adrenal function (Allen et al., 1973).

Although stressful stimuli have been reported to induce CRF mRNA accumulation in the PVN, the regulation of CRF gene expression in other brain areas has been less thoroughly studied. In addition to its effects on the pituitary, CRF has been implicated as playing a role in several behavioral, neuroendocrine, and autonomic responses to stress (Brown and Fisher, 1985; Koob and Bloom, 1985). Our in situ hybridization data showed that both acute and chronic footshock stress induced a marked accumulation of CRF mRNA in an autonomic-related cell group,
Barrington's nucleus, as reflected by increases in the density of silver grains per cell, as well as in the number of cells exhibiting a positive hybridization signal. Unlike the PVN, however, manipulation of the steroid environment did not affect CRF mRNA expression in this cell group. This, coupled with the fact that mRNA levels in Barrington's nucleus were markedly affected by both acute and chronic stress, is consistent with the view that the effects of stress on CRF mRNA in the PVN may be dampened by heightened corticosteroid feedback.

Previous studies on the distribution of CRF-like immunoreactivity in the rat brain have reported CRF-positive neurons in various cells groups of the dorsolateral pontine tegmentum, including the locus coeruleus, the laterodorsal tegmental nucleus, and Barrington's nucleus (Olschowka et al., 1982a,b; Cummings et al., 1983; Swanson et al., 1983; Sawchenko and Swanson, 1990). Some confusion has arisen due to the fact that these cell groups are closely juxtaposed, and the term "laterodorsal tegmental nucleus" has previously been applied to what is currently known as Barrington's nucleus, a circumscribed cluster of cells that projects to the sacral parasympathetic nucleus (Loewy et al., 1979), as well as to a more broadly distributed group of cholinergic neurons whose major projections are to the forebrain (e.g., Rye et al., 1987). It now seems clear that the principal site housing CRF-immunoreactive neurons in this region corresponds to Barrington's nucleus (Vincent and Satoh, 1984; Sakanaka et al., 1987; Sutin and Jacobowitz, 1988). The results of the present study provide strong support for this view, in that we have demonstrated that CRF mRNA is prominently expressed in Barrington's nucleus using in situ hybridization. The specificity of the ${ }^{35} \mathrm{~S}$-radiolabeled RNA probe used in this study has been previously demonstrated using Northern blot analysis and in situ hybridization (Imaki et al., 1989). In addition, no specific hybridization was found in Barrington's nucleus using a sense-oriented CRF probe. 
Barrington's nucleus plays an important role in the central regulation of micturition (Kuru, 1965). Bilateral destruction of the nucleus results in an inability to void the bladder (Barrington, 1925; Satoh et al., 1978), and stimulation of the nucleus induces contraction of the detrusor of the urinary bladder and urination (Wang and Ranson, 1939; Yamamoto, 1962). However, the neuroactive agents contained within in this system have not been well established. Apart from CRF, several peptides (atrial natriuretic factor, dynorphin, and somatostatin) have been reported to be localized in perikarya in the region of Barrington's nucleus by immunohistochemistry (Standaert et al., 1986; Sutin and Jacobowitz, 1988), though the extent to which they may be contained in projections to the sacral spinal cord remains to be established. The presence of CRF peptide and mRNA in Barrington's nucleus suggest a role for CRF as a neurotransmitter or neuromodulator of prominence in the supraspinal control of micturition.

Stress is known to stimulate reflex micturition in many species, including rodents (Hall, 1934; Irwin, 1965). Our observation of enhanced CRF mRNA expression in Barrington's nucleus following footshock stress provides another example to support the notion that CRF may be involved in a variety of central endocrine, autonomic, and behavioral systems subserving components of the integrated organismic responses to stress. Previously, Chappell et al. (1986) have reported that CRF-like immunoreactivity in micropunch samples of the locus coeruleus increased after acute and chronic stress. Because of the proximity of the locus coeruleus to Barrington's nucleus, and the paucity of evidence for substantial CRF expression in the former, it would seem quite likely that stress effects on peptide levels in Barrington's nucleus could account for these findings.

Two major factors made it of interest to include a consideration of the olfactory bulb in the present analysis: (1) Tissue levels of CRF mRNA are particularly high here, greater even than in the whole hypothalamus (Imaki et al., 1989). (2) The bulb provided an interesting contrast to the other cell groups studied, in that as a chemosensory structure, there existed little a priori reason to suspect that CRF mRNA here should respond similarly to that in the PVN and Barrington's nucleus, which might be construed as being involved, respectively, in neuroendocrine and autonomic responses common to many stressors. In the olfactory bulb, acute and chronic stress led to a robust down-regulation of CRF mRNA, which could be localized to both mitral and tufted cells, the principal output neurons of the bulb. Nevertheless, similar effects were seen in a group of shamhandling controls, which were placed in shock chambers, but never experienced footshock. I his suggests that the decrease in CRF mRNA levels seen in the stressed group did not result from footshock per sc, but may be related to other factors including handling, isolation, and/or novelty. It is possible, therefore, that CRF gene expression in the olfactory bulb is regulated by odorants, which could presumably modulate neuronal activities of mitral and tufted cells and/or their targets (Moulton, 1965, 1976). The observation that CRF mRNA levels in the olfactory bulb were changed after exposure to a novel environment supports this notion. Although CRF is one of the most prominently and widely distributed neuroactive agents yet described in the olfactory bulb (Imaki et al., 1989), a fast amino acid-like neurotransmitter, most probably $N$-acetylasparatylglutamate, has been demonstrated in mitral and tufted cells and most probably serves as the principal neurotransmitter in the primary olfactory cortex (Halasz and Shepherd, 1983; Macrides and Davis, 1983; Ffrench-Mullen et al., 1985; Anderson et al., 1986; Blakely et al., 1987). CRF may thus act as a cotransmitter or neuromodulator in the olfactory system; sensitivity of its biosynthetic machinery to the stress of handling and/or environmental novelty could indicate a mechanism by which stress might modulate olfactory information processing.

It is by no means clear that the effects of stress on CRF mRNA expression are necessarily limited to the 3 cell groups considered here. While our Northern blot analysis failed to reveal effects of stress or pertubations of the steroid environment in other grossly dissected brain areas (cerebral cortex, midbrain, and brain stem), each of these regions comprise heterogeneous CRFexpressing cell groups and cell types. Because coarse sampling procedures could well dilute highly localized and/or differential effects of stress within any or all of these areas, it will remain for hybridization histochemical analyses to test the generalizations suggested by the present results and to define fully the regulation of CRF $m$ RNA expression at the cellular level.

\section{References}

Allen JP, Allen CF, Greer MA, Jacobs JJ (1973) Stress-induced secretion of ACTH. In: Brain-pituitary-adrenal interrelationships (Brodish S, Redgate ES, eds), pp 99-127. Basel: Karger.

Anderson KJ, Monaghan DT, Cangro CB, Namboodiri MAA, Neale $\mathrm{JH}$, Cotman CW (1986) Localization of $N$-acetylaspartylglutamatelike immunoreactivity in selected areas of the rat brain. Neurosci Lett 72:14-20.

Antoni FA (1986) Hypothalamic control of adrenocorticotropin secretion: advances since the discovery of 41 -residue corticotropinreleasing factor. Endocrine Rev 7:351-370.

Barrington FJT (1925) The effect of lesion of the hind- and midbrain on micturition in the cat. Q J Exp Physiol 15:81-102.

Beyer HS, Matta SG, Sharp BM (1988) Regulation of the messenger ribonucleic acid for corticotropin-releasing factor in the paraventricular nucleus and other brain sites of the rat. Endocrinology 123:21172123.

Blakely RD, Ory-I avollee I., Granna R, Koller KJ, Coyle JT (1987) Selective immunochemical staining of mitral cells in rat olfactory bulb with affinity purified antibodies against $N$-acetyl-aspartyl-glutamate. Brain Res 402:373-378.

Brown MR, Fisher LA (1985) Corticotropin-releasing factor: effects on the autonomic nervous system and visceral systems. Fed Proc 44: 243-248.

Chappell PB, Smith MA, Kilts CD, Bissette G, Ritchie J, Anderson C, Nemeroff CB (1986) Alterations in corticotropin-releasing factorlike immunoreactivity in discrete rat brain regions after acute and chronic stress. J Neurosci 6:2908-2914.

Chomczynski P, Sacchi N (1987) Single-step method of RNA isolation by acid-guanidium thiocyanate-phenol-chloroform extraction. Anal Biochem 162:156-159.

Cummings S, Elde R, Ells J, I indall A (1983) Corticotropin-releasing factor immunoreactivity is widely distributed within the central nervous systemı of the rat: an immunohistochemical study. J Neurosci 3:1355-1368

Ffrench-Mullen JMH, Koller K, Zacek R, Coyle JT (1985) $N$-acetylaspartyl-glutamate: possible role as the neurotransmitter of the lateral olfactory tract. Proc Natl Acad Sci USA 82:3897-3900.

Fremeau RT Jr, Lundblad JR, Pritchett DB, Wilcox JN, Roberts JL (1986) Regulation of pro-opiomelanocortin gene transcription in individual cell nuclei. Science 234:1265-1269.

Glowinski J, Iverson LL (1966) Regional studies of catecholamine in the rat brain I: The disposition of $\left[{ }^{3} \mathrm{H}\right]$-norepinephrine, $\left[{ }^{3} \mathrm{H}\right]$-dopamine and $\left[{ }^{3} \mathrm{H}\right]$-dopa in various regions of the brain. J Neurochem 13 : 655-669.

Greer MA, Allen CF, Gibbs FP, Gullickson C (1970) Pathways at the hypothalamic level through which traumatic stress activates ACTH secretion. Endocrinology 86:1404-1409.

Haas DA, Gcorgc SR (1988) Singlc or repcatcd mild stress increases synthesis and release of hypothalamic corticotropin-releasing factor. Brain Res 461:230-237. 
Halasz N, Shepherd GM (1983) Neurochemistry of the vertebrate olfactory bulb. Neuroscience 10:579-619.

Hall CS (1934) Emotional behavior in the rat: I. Defecation and urination as measures of individual differences in emotionality. J Comp Physiol 18:385-403.

Harbuz MS, Lightman SL (1989) Responses of hypothalamic and pituitary mRNA to physical and psychological stress in the rat. $J$ Endocrinol 122:705-711.

Herman JP, Schafer MK-H, Sladek CD, Day R, Young EA, Akil H, Watson SJ (1989) Chronic electroconvulsive shock treatment elicits up-regulation of CRF and AVP in select populations of neuroendocrine neurons. Brain Res 501:235-246.

Hiroshige T, Fujieda K, Kaneko M, Honma K (1977) Assays and dynamics of corticotropin-releasing factor activity in rat hypothalamus. Ann NY Acad Sci 297:436-454.

Holt V, Prewtocki R, Haarmann I, Almeida OFX, Kley N, Millan MJ, Herz A (1986) Stress-induced alterations in the levels of messenger RNA coding proopiomelanocortin and prolactin in rat pituitary. Neuroendocrinology 43:277-282.

Imaki T, Nahon J-L, Sawchenko PE, Vale WW (1989) Widespread expression of corticotropin-releasing factor messenger RNA and immunoreactivity in the rat olfactory bulb. Brain Res 496:35-44.

Irwin S (1965) Gorden research conference on medical chemistry 1959 In: Screening methods in pharmacology (Turner RA, ed), p 33. New York: Academic.

Jingami H, Mizuno N, Takahashi $\mathrm{H}$, Shibahara S, Furutani $\mathrm{Y}$, Imura $\mathrm{H}$ Numa $S$ (1985a) Cloning and sequence analysis of cDNA for rat corticotropin-releasing factor precursor. FEBS Lett 191:63-66.

Jingami H, Matsukura S, Numa S, Imura H (1985b) Effects of adrenalectomy and dexamethasone administration on the level of preprocorticotropin-releasing factor messenger ribonucleic acid (mRNA) in the hypothalamus and adrenocorticotropin/ $\beta$-lipotropin precursor mRNA in the pituitary in rats. Endocrinology 117:1314-1320.

Kant GJ, Mougey EH, Pennington LL, Meyerhoff JL (1983) Graded footshock stress elevates pituitary cyclic AMP and plasma $\beta$-endorphin, $\beta$-LPH, corticosterone and prolactin. Life Sci 33:2657-2663.

Koob GF, Bloom FE (1985) Corticotropin-releasing factor and behavior. Fed Proc 44:259-263.

Kovacs K, Mezey E (1987) Dexamethasone inhibits corticotropinrelcasing factor gene expression in the rat paraventricular nucleus. Neuroendocrinology 46:365-368.

Kuru M (1965) Nervous control of micturition. Physiol Rev 45:425494.

Lightman SL, Young WS III (1988) Corticotropin-releasing factor, vasopressin and pro-opiomelanocortin mRNA responses to stress and opiates in the rat. J Physiol (Lond) 403:51 1-523.

Lightman SL, Young WS III (1989) Influence of steroids on the hypothalamic corticotropin-releasing factor and preproenkephalin mRNA responses to stress. Proc Natl Acad Sci USA 86:4336-4310.

Loewy AD, Saper CB, Baker RP (1979) Descending projections from the pontine micturition center. Brain Res 172:533-538.

Macrides F, Davis BJ (1983) The olfactory bulb. In: Chemical neuroanatomy (Emson PC, ed), pp 391-426. New York: Raven.

Moldow RL, Fischman AJ (1982) Physiological changes in rat hypothalamic CRF: circadian, stress and steroid suppression. Peptides $3: 837-840$.

Moldow RL, Kastin AJ, Graf M, Fischman AJ (1986) Stress mediated changes in hypothalamic corticotropin-releasing factor-like immunoreactivity. Life Sci 40:413-418.

Moulton DG (1965) Electrical activity in the olfactory system of rabbits with indwelling electrodes. In: Olfaction and taste (Zotterman IY, ed), pp 71-84. Oxford: Pergamon.

Moulton DG (1976) Spatial patterning of response to odors in the peripheral olfactory system. Physiol Rev 56:578-593.

Olschowka JA, O'Donohue TL, Mueller GP, Jacobowitz DM (1982a) Hypothalamic and extrahypothalamic distribution of CRF-like immunoreactive neurons in the rat brain. Neuroendocrinology 35:305308.

Olschowka JA, O'Donohue TL, Mueller GP, Jacobowitz DM (1982b) The distribution of corticotropin-releasing factor-like immunoreactive neurons in rat brain. Peptides 3:995-1015.

Plotsky PM, Vale W (1984) Hemorrhage-induced secretion of corticotropin-releasing factor-like immunoreactivity into the rat hypophysial portal circulation and its inhibition by glucocorticoids. Endocrinology 114:164-169.
Plotsky PM, Otto S, Sapolsky RM (1986) Inhibition of immunoreactive corticotropin-releasing factor secretion into the hypophyseal-portal circulation by delayed glucocorticoid feedback. Endocrinology 119: $1126-1130$

Rivier C, Vale W (1987) Diminished responsiveness of the hypothalamic-pituitary-adrenal axis of the rat during exposure to prolonged stress: a pituitary mediated mechanism. Endocrinology 121:13201328 .

Rivier C, Rivier J, Vale W (1982) Inhibition of adrenocorticotropic hormone secretion in the rat by immunoneutralization of corticotropin-releasing factor. Science 218:377-379.

Rivier CL, Plotsky PM (1986) Mediation by corticotropin-releasing factor (CRF) or adenohypophyseal hormone secretion. Annu Rev Physiol 48:475-494.

Rivier J, Spiess J, Vale W (1982) Characterization of rat hypothalamic corticotropin-releasing factor. Proc Natl Acad Sci USA 80:4851-4855.

Robinson BG, Mealy K, Wilmore DW, Majzoub JA (1989) The effects of insulin hypoglycemia on gene expression in the hypothalamic pituitary adrenal axis of the unanesthetized rat. Abstr Endocrine Soc $71: 260$.

Rye DB, Saper CB, Lee HJ, Wainer BH (1987) Pedunculopontine tegmental nucleus of the rat: cytoarchitecture, cytochemistry, and some extrapyramidal connections of the mesopontine tegmentum. J Comp Neurol 259:483-528.

Sakanaka M, Shibasaki T, Lederis K (1987) Corticotropin-releasing factor-like immunoreactivity in the rat brain as revealed by a modified cobalt-glucose oxidase-diaminobenzidine method. J Comp Neurol 260:256-298

Sato T, Sato M, Shinsako J, Dallman MF (1975) Corticosteroneinduced changes in hypothalamic corticotropin-releasing factor (CRF) content after stress. Endocrinology 97:265-274.

Satoh K, Shimizu N, Tohyama M, Maeda T (1978) Localization of the micturition reflex center at dorsolateral pontine tegmentum of the rat. Neurosci Lett 8:27-33.

Sawchenko PE, Swanson LW (1990) Organization of CRF immunoreactive cells and fibers in the rat brain: immunohistochemical studies. In: Corticotropin-releasing factor: basic and clinical studies of a neuropeptide (DeSouza EB, Nemeroff CB, eds), pp 29-51. Boca Raton: CRC Uniscience.

Shibahara S, Morimoto Y, Furutani Y, Notake M, Takahashi H, Shimizu $S$, Horikawa $S$, Numa $S$ (1983) Isolation and sequence analysis of the human corticotropin-releasing factor precursor gene. EMBO J 2:775-779.

Simmons DM, Arriza JL, Swanson LW (1989) A complete protocol for in situ hybridization of messenger RNAs in brain and other tissues with radiolabeled single-stranded RNA probes. J Histotechnol 12: 169-181.

Standaert DG, Needleman P, Saper CB (1986) Organization of atriopeptin-like immunoreactive neurons in the central nervous system of the rat. J Comp Neurol 253:315-341.

Sternberg EM, Young WS III, Bernardini R, Calogero A, Chrousos GP, Gold PW, Wilder RL (1989) A central nervous system defect in biosynthesis of corticotropin-releasing hormone is associated with susceptibility to streptococcal cell wall-induced arthritis in Lewis rats. Proc Natl Acad Sci USA 86:4771-4775.

Suda T, Yajima F, Tomori N, Demura H, Shizume K (1985) In vitro study of immunoreactive corticotropin-releasing factor release from the rat hypothalamus. Life Sci 37:1499-1505.

Suda T, Tozawa F, Yamada M, Ushiyama T, Tomori N, Sumitomo T, Nakagami $Y$, Demura H, Shizume K (1988) Insulin-induced hypoglycemia increases corticotropin-releasing factor messenger ribonucleic acid levels in rat hypothalamus. Endocrinology 123:13711375.

Suemaru S, Hashimoto K, Ota Z (1985) Brain corticotropin-releasing factor (CRF) and catecholamine responses in acutely stressed rats. Endocrinol Jpn 32:709-718.

Sutin EL, Jacobowitz DM (1988) Immunocytochemical localization of peptides and other neurochemicals in the rat laterodorsal tegmental nucleus and adjacent area. J Comp Neurol 270:243-270.

Swanson LW, Simmons DM (1989) Differential steroid hormone and neuronal influence on peptide mRNA levels in CRH cells of the paraventricular nucleus: a hybridization histochemical study in the rat. J Comp Neurol 285:413-435.

Swanson LW, Sawchenko PE, Rivier J, Vale W (1983) Organization of ovine corticotropin-releasing factor immunoreactive cells and fi- 
bers in the rat brain: an immunohistochemical study. Neuroendocrinology 36:165-186.

Switzer RC, DeOlmos J, Heimer L (1985) Olfactory system. In: The rat nervous system (Paxinos $\mathrm{G}$, ed), pp 1-36. Orlando: Academic.

Vale W, Spiess J, Rivier C, Rivier J (1981) Characterization of a 41residue ovine hypothalamic peptide that stimulates secretion of corticotropin and beta endorphin. Science 213:1394-1397.

Vale W, Rivier C, Brown MR, Spiess J, Koob G, Swanson L, Bilezikjian L, Bloom F, Rivier J (1983) Chemical and biological characterization of corticotropin releasing factor. Rec Prog Hormone Res 39:245270.

Vincent SR, Satoh K (1984) Corticotropin-releasing factor (CRF) immunoreactivity in the dorsolateral pontine tegmentum: further studies on the micturition reflex system. Brain Res 308:387-391.
Wang SC, Ranson SW (1939) Autonomic responses to electrical stimulation of the lower brain stem. J Comp Neurol 71:437-455.

Watts AG, Swanson LW (1989) Diurnal variations in the content of preprocorticotropin-releasing hormone messenger ribonucleic acids in the hypothalamic paraventricular nucleus of rats of both sexes as measured by in situ hybridization. Endocrinology 125:1734-1738.

Yamamoto $\mathrm{H}$ (1962) Experimental studies on the fiber connections of the pontine micturition facilitatory area in the cat. Osaka Daigaku Igaku Zasshi 14:247-263.

Young WS III, Mezey E, Siegel RE (1986) Quantitative in situ hybridization histochemistry reveals increased levels of corticotropinreleasing factor mRNA after adrenalectomy in rats. Neurosci Lett 70 : 198-203. 